\title{
MWMII Effect of Patient Navigation on Breast Cancer Screening Among African American Medicare Beneficiaries: A Randomized Controlled Trial
}

\author{
Jessie Kimbrough Marshall, $M D M P H^{7}$, Olive M. Mbah, $M H S^{2}$, Jean G. Ford, $\mathrm{MD}^{3}$, \\ Darcy Phelan-Emrick, DrPH, MHS', Saifuddin Ahmed, PhD 5,6, Lee Bone, MPH, RN ${ }^{7}$, \\ Jennifer Wenzel, PhD, RN 2,8, Gary R. Shapiro, MD', Mollie Howerton, PhD, MPH ${ }^{10}$, \\ Lawrence Johnson, MD ${ }^{17}$, Qiana Brown, PhD, MPH, MSW ${ }^{12}$, Altovise Ewing, PhD ${ }^{13}$, and Craig Evan \\ Pollack, MD ${ }^{4} 14$
}

\begin{abstract}
'Division of General Medicine, University of Michigan Health System, Ann Arbor, MI, USA; ${ }^{2}$ Department of Oncology, Johns Hopkins School of Medicine, Baltimore, MD, USA; ${ }^{3}$ Department of Medicine, The Brooklyn Hospital Center, Brooklyn, NY, USA; ${ }^{4}$ Department of Epidemiology, Johns Hopkins Bloomberg School of Public Health, Baltimore, MD, USA; 5 Department of Population, Family and Reproductive Health, Johns Hopkins Bloomberg School of Public Health, Baltimore, MD, USA; 'Department of Biostatistics, Johns Hopkins Bloomberg School of Public Health, Baltimore, MD, USA; ${ }^{7}$ Department of Health, Behavior and Society, Johns Hopkins Bloomberg School of Public Health, Baltimore, MD, USA; ${ }^{8}$ Department of Acute and Chronic Care, Johns Hopkins School of Nursing, Baltimore, MD, USA; ${ }^{3}$ Health Partners Cancer Program and Institute for Education and Research, Minneapolis, MN, USA; ${ }^{10}$ Centers for Medicare and Medicaid Services, Baltimore, MD, USA; ${ }^{1}$ Park West Health Systems, Baltimore, MD, USA; ${ }^{12}$ TVCOFA Corporation, Baltimore, MD, USA; ${ }^{13}$ Formerly of the Department of Health, Behavior and Society, Johns Hopkins Bloomberg School of Public Health, Baltimore, MD, USA; ${ }^{14}$ Department of Medicine, Johns Hopkins School of Medicine, Baltimore, MD, USA.
\end{abstract}

BACKGROUND: There is growing evidence that patient navigation improves breast cancer screening rates; however, there are limited efficacy studies of its effect among African American older adult women.

OBJECTIVE: To evaluate the effect of patient navigation on screening mammography among African American female Medicare beneficiaries in Baltimore, MD.

DESIGN: The Cancer Prevention and Treatment Demonstration (CPTD), a multi-site study, was a randomized controlled trial conducted from April 2006 through December 2010.

SETTING: Community-based and clinical setting.

PARTICIPANTS: The CPTD Screening Trial enrolled 1905 community-dwelling African American female Medicare beneficiaries who were $\geq 65$ years of age and resided in Baltimore, MD. Participants were recruited from health clinics, community centers, health fairs, mailings using Medicare rosters, and phone calls.

INTERVENTIONS: Participants were randomized to either: printed educational materials on cancer screening (control group) or printed educational materials + patient navigation services designed to help participants overcome barriers to cancer screening (intervention group).

MAIN MEASURE: Self-reported receipt of mammography screening within 2 years of the end of the study.

KEY RESULTS: The median follow-up period for participants in this analysis was 17.8 months. In weighted multivariable logistic regression analyses, women in the intervention group had significantly higher odds of being up to date on mammography screening at the end of the follow-up period compared to women in the control group

NIH trial registry number: NCTO0379743

Received September 14, 2014

Revised January 12, 2015

Accepted February 4, 2015

Published online August 11, 2015 (odds ratio [OR] 2.26, $95 \%$ confidence interval [CI] 1.593.22). The effect of the intervention was stronger among women who were not up to date with mammography screening at enrollment (OR 3.63, 95 \% CI 2.09-6.38).

CONCLUSION: Patient navigation among urban African American Medicare beneficiaries increased self-reported mammography utilization. The results suggest that patient navigation for mammography screening should focus on women who are not up to date on their screening.

KEY WORDS: patient navigation; mammography; African American.

J Gen Intern Med 31(1):68-76

DOI: $10.1007 / \mathrm{s} 11606-015-3484-2$

(C) Society of General Internal Medicine 2015

\section{INTRODUCTION}

Breast cancer remains the second leading cause of cancer death among women in the US, ${ }^{1-3}$ with widespread racial/ ethnic disparities that span the cancer continuum. ${ }^{4-7}$ Compared to other racial/ethnic groups, African American women have the highest breast cancer mortality rates, ${ }^{2,8}$ including among older adults. ${ }^{2}$ Lack of mammography screening and late diagnosis have been shown to contribute to these disparities, ${ }^{7,9-14}$ highlighting the need for interventions that address racial/ethnic screening disparities.

Patient navigation is a promising approach to reducing disparities in breast cancer screening. ${ }^{14-16}$ Patient navigators, often members of the community who are fluent in the patient's language and sensitive to her culture, help address barriers to care. ${ }^{14}$ For example, patient navigators can assist individuals in overcoming obstacles to cancer screening, including difficulty with insurance coverage, lack of transportation, and poor comprehension of treatment plans. ${ }^{17-19}$ These 
barriers are commonly reported among older African American women, who also report difficulty accessing health care and high levels of mistrust of the health care system. ${ }^{20}$

A growing body of literature has shown the success of patient navigation in improving breast cancer screening;21-29 however, most of these studies were restricted to patients recruited in clinical settings, ${ }^{22,26,27}$ lacked a control group, and/or did not use a randomized controlled design. $^{21,22,25,26,28,29}$ Furthermore, few studies have examined the effect of patient navigation on breast cancer screening in the Medicare population (adults 65 years of age and over), focused exclusively on African American women, ${ }^{30}$ or used a community-informed research design. ${ }^{31-34}$ Programs in partnership with the community that focus on specific underserved populations may offer an important corrective to existing disparities. $^{35}$

The objective of this study was to examine the effect of patient navigation on screening mammography among African American female Medicare beneficiaries in Baltimore, MD. We further examined the role of screening history, health literacy and age as potential moderators of the relationship between patient navigation and mammography screening. We hypothesized that patient navigation would be more beneficial among women who had not been screened previously and would help address difficulties commonly faced among women with low health literacy. With guidelines uncertain about the benefit of mammography in women age 75 and older, ${ }^{3,36}$ we further hypothesized that the intervention would be more effective among younger women.

\section{METHODS}

\section{Study Setting, Design and Participants}

We present data from the Cancer Prevention and Treatment Demonstration (CPTD) Screening Trial, a national 4-year (April 2006 through December 2010) multi-site project that evaluated patient navigation as a strategy to reduce ethnic and racial disparities in cancer screening. ${ }^{31,37-40}$ The current study focuses on the CPTD in Baltimore City, MD, one of the six sites in the national demonstration project.

Both convenience- and population-based sampling were used to recruit participants in Baltimore City, MD, from November 2006 through March 2010. Convenience sampling was performed by study staff in clinical settings and community-based settings (e.g., senior centers and health fairs). For the population-based sampling, a list of Medicare enrollees was used to contact potentially eligible participants by mail and phone. Study letters were periodically mailed to African American Medicare enrollees in Baltimore City. Potential participants within each mailing cycle were then contacted by phone and screened for eligibility, until we reached our recruitment goal. Over 20,000 letters were mailed during the course of the study. Through these two recruitment methods, 3536 individuals were assessed for eligibility, from which
2593 participants were enrolled (73.3\%), 1905 of whom were women (see Fig. 1).

Participants were eligible if they were age $\geq 65$ years, selfreported African American, enrolled in fee-for-service Medicare Parts A \& B, and a Baltimore City resident. Exclusion criteria included enrollment in a Medicare managed care plan, a diagnosis of cancer within the past 5 years or a diagnosis of cancer not in remission, the inability to provide informed consent, and current residence in a chronic care facility or otherwise institutionalized. Only one individual per household was eligible to participate in the study. This analysis was restricted to women who provided exit data by the end of the study period in December 2010.

After completion of an in-person baseline questionnaire, participants were randomized 1:1 to either printed educational materials only (PEM - control group) or educational materials plus patient navigation services (intervention group). Followup interviews with both groups were repeated annually for the duration of participants' enrollment and there was an exit interview conducted at the end of the study period (2010). In both study groups, these interviews were performed either in person or over the phone.

The maximum follow-up time from baseline to exit screening for the CPTD study participants was 45.6 months [mean (range), 17.8 months (2 to 45.6 months)]. All trial participants provided written informed consent. The Johns Hopkins School of Public Health's Institutional Review Board approved this study.

\section{Interventions}

Printed Educational Materials (PEM). Participants randomized to the control group received educational materials developed by CMS, containing general information about cancer and preventive services covered by Medicare.

Patient Navigation. Participants in the patient navigation intervention group received the same PEM plus patient navigation services. Navigation focused on multiple cancer screenings including breast cancer. Navigator training included didactic classroom time, interactive role playing, shadowing of navigators and instruction in the use of an electronic database specially designed to support the navigators' patient education and in which all navigation activities were documented. ${ }^{31}$ Navigators made introductory phone calls to participants shortly after their baseline interview to introduce their role as screening facilitators, review participants' baseline cancer screening status, discuss printed educational materials, consider predisposing factors to cancer screening (e.g., perceptions and beliefs about cancer), and identify potential barriers. Navigators helped arrange appointments and accompany participants to screenings when necessary. Navigators also worked to enhance the patient-provider interaction by coaching patients on potential questions to ask their providers. An oncology nurse specialist 


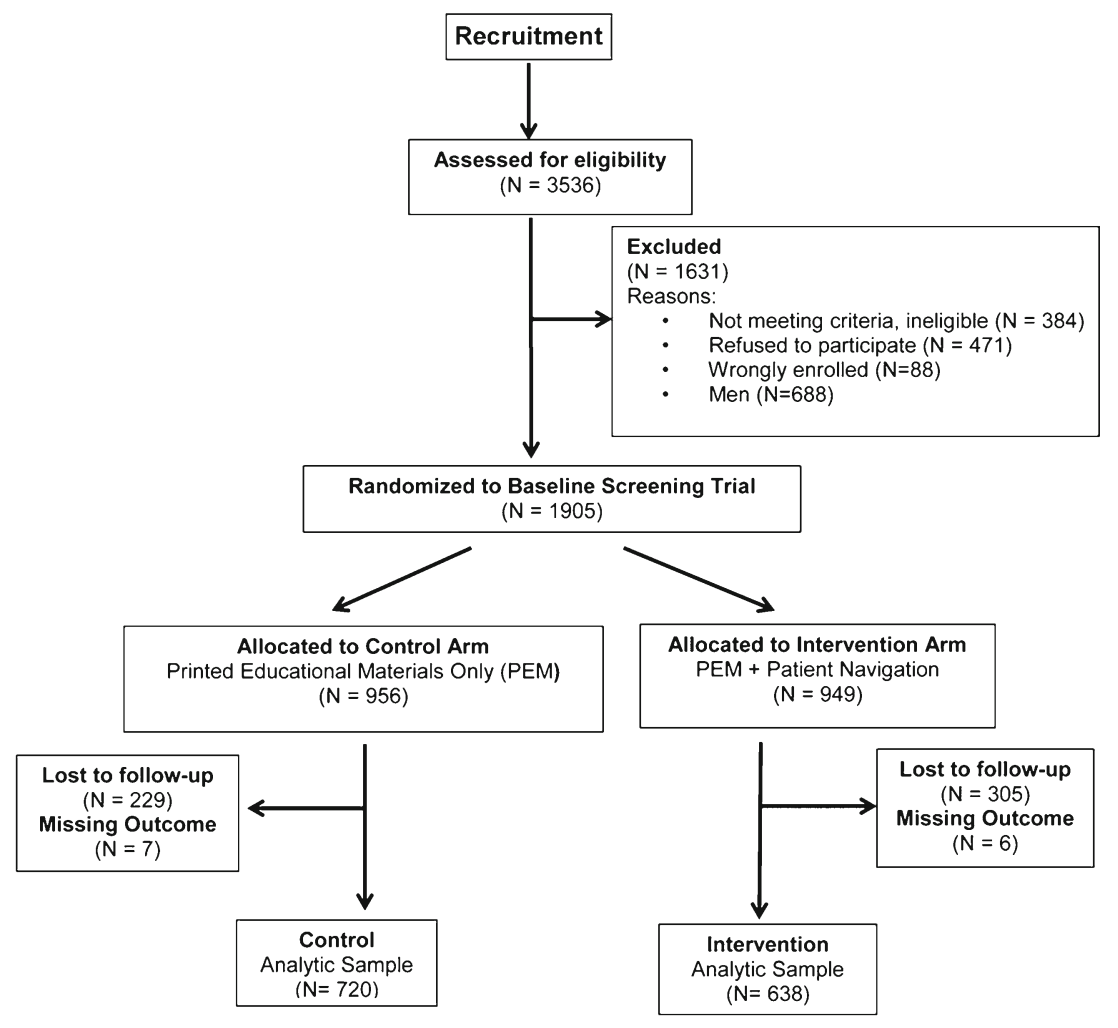

Fig. 1 Study participant flow chart. PEM = printed educational materials

was available to the patient navigation team to answer questions and provide clinical support.

Navigators made both in-person and phone-based contact, and managed caseloads of 100 to 300 participants. Patient navigators were expected to have, at a minimum, quarterly contact with participants by phone or in person. Participants who were up to date on their cancer screenings or indicated no barriers to getting screened received quarterly contact from navigators whereas more frequent contact occurred when the navigators were actively helping overcome barriers. For participants who were difficult to reach, navigators made frequent attempts to engage through letters or reaching out to participants' back up contact. ${ }^{31}$

Over the course of the study, the majority of patient navigators were African American (71\%). All were women and came from Baltimore City and the greater Baltimore area. ${ }^{31}$ The patient navigation program of the CPTD study was developed using a community-academic participatory approach including the formation of a community advisory committee. $^{31}$

\section{Main Outcome Measure}

Our primary outcome variable for this analysis was selfreported receipt of mammography screening. At the exit interview, participants were asked whether they had ever had a mammogram, and if yes, the time interval from their last screening was collected. Women were considered up to date if they reported receipt of a mammogram during the preceding 24 months.

\section{Control Variables}

Data for all other variables were collected at baseline. Participant sociodemographic characteristics included age $(>75$ or $\leq 75$ years old), marital status, education $(<12$ th grade, completion of 12 th grade, or $>12$ th grade) and income $(<$ $\$ 20,000 /$ year or $\geq \$ 20,000 /$ year). Co-insurance was defined as supplemental private insurance, Medigap, or Medicaid. Women were defined as being up to date at baseline if they reported having received a mammogram within the preceding 24 months. Participants' risk of low health literacy skills was assessed with the Rapid Estimate of Adult Literacy in Medicine-Revised (REALM-R) instrument. ${ }^{41}$ Participants with a score of $\leq 6$ were classified as having low health literacy; a score of 6 corresponds to a sixth grade reading level and is associated with difficulty comprehending written and oral materials. ${ }^{41,42}$ Family history of breast cancer was assessed by the question, "Have your grandmother, mother, sister, or daughter ever been diagnosed with breast cancer?" Participants' comorbidities were a tally of the number of self-reported medical conditions from the following list: hypertension, diabetes, chronic lung disease, coronary heart disease or other heart problems, stroke, gastrointestinal problems, psychiatric disorders, arthritis, and memory-related disease. This variable was dichotomized at the sample mean $(<3$ or $\geq 3)$. 


\section{Statistical Analyses}

Pearson's chi-squared test was used to first compare demographic and health characteristics between participants in each study arm and second to compare characteristics of participants who were and were not lost to follow-up. We then used logistic regression models to estimate whether women in the patient navigation arm had increased odds of being up to date with mammograms at exit compared to women in the PEM arm, adjusting for participant covariates. Due to the high rate of loss to follow-up, we used the inverse probability method to weight our multivariable logistic regression models. ${ }^{43,44}$ In this approach, weights are used from regression models based on baseline characteristics and study arm assignment. Greater weight is given to participants who would otherwise be underrepresented in the analyses due to attrition. Overall, rates of missingness for study variables ranged from $0 \%$ to $5.6 \%$, except for income which had a missing rate of $17.9 \%$. We used the multiple imputation chained equations (ICE) method to impute responses for covariates. In sensitivity analyses, we compared weighted and unweighted models and tested models without the income variable, finding similar results. We then tested whether the intervention worked differently among specific subsets of the population. In separate models, we tested interactions between the intervention and baseline mammogram status, health literacy, and patient age. All analyses were performed using STATA/IC version 11.0 software (StataCorp LP, College Station, TX).

\section{RESULTS}

\section{Baseline Characteristics of Study Participants}

Baseline characteristics of study participants by intervention group are shown in Table 1 . The majority of women were $\leq 75$ years old $(70 \%)$, had at least a high school diploma (73\%), and had an annual household income of $<\$ 20,000$ $(53.5 \%)$. At baseline, $88 \%$ of participants reported having had a screening mammogram within the past 2 years. With the exception of marital status, there were no significant differences in observable characteristics between study arms. More women in the intervention group were married or living with a partner than in the control group (24.6 vs. 18.9 , respectively, $p=0.04$ ).

Table 1 Baseline characteristics of study participants by intervention group

\begin{tabular}{|c|c|c|c|c|}
\hline & Total & $\begin{array}{l}\text { Control group (printed } \\
\text { education materials only) }\end{array}$ & $\begin{array}{l}\text { Intervention group (patient } \\
\text { navigation }+ \text { PEM) }\end{array}$ & \\
\hline Variable & $(N=1358)$ & $(N=720)$ & $(N=638)$ & $P$ value ${ }^{*}$ \\
\hline & $\mathrm{N}(\%)$ & $\mathrm{N}(\%)$ & $\mathrm{N}(\%)$ & \\
\hline $\begin{array}{l}\text { Age group (years) } \\
>75 \\
\leq 75\end{array}$ & $\begin{array}{l}398(29.3) \\
960(70.7)\end{array}$ & $\begin{array}{l}216(30.0) \\
504(70.0)\end{array}$ & $\begin{array}{l}182(28.5) \\
456(71.5)\end{array}$ & 0.55 \\
\hline Education & & & & \\
\hline $\begin{array}{l}\text { < High school diploma } \\
\text { High school diploma } \\
\text { > High school diploma }\end{array}$ & $\begin{array}{l}362(27.0) \\
363(27.0) \\
618(46.0)\end{array}$ & $\begin{array}{l}190(26.7) \\
201(28.3) \\
320(45.0)\end{array}$ & $\begin{array}{l}172(27.2) \\
162(25.6) \\
298(47.2)\end{array}$ & 0.54 \\
\hline Income & & & & \\
\hline $\begin{array}{l}<\$ 20,000 \\
\geq \$ 20,000\end{array}$ & $\begin{array}{l}596(53.5) \\
519(46.5)\end{array}$ & $\begin{array}{l}330(55.1) \\
269(44.9)\end{array}$ & $\begin{array}{l}266(51.5) \\
250(48.5)\end{array}$ & 0.24 \\
\hline Family history of $\mathrm{BC}$ & & & & \\
\hline $\begin{array}{l}\text { No } \\
\text { Yes }\end{array}$ & $\begin{array}{l}1063(79.6) \\
273(20.4)\end{array}$ & $\begin{array}{l}567(80.4) \\
138(19.6)\end{array}$ & $\begin{array}{l}496(78.6) \\
135(21.4)\end{array}$ & 0.41 \\
\hline Comorbidities & & & & \\
\hline $\begin{array}{l}<3 \\
\geq 3\end{array}$ & $\begin{array}{l}510(38.7) \\
808(61.3)\end{array}$ & $\begin{array}{l}266(38.0) \\
434(62.0)\end{array}$ & $\begin{array}{l}244(39.5) \\
374(60.5)\end{array}$ & 0.58 \\
\hline Mēdicaid & & & & \\
\hline $\begin{array}{l}\text { No } \\
\text { Yes }\end{array}$ & $\begin{array}{l}1158(86.9) \\
174(13.1)\end{array}$ & $\begin{array}{l}622(88.2) \\
83(11.8)\end{array}$ & $\begin{array}{l}536(85.5) \\
91(14.5)\end{array}$ & 0.14 \\
\hline Medigap & & & & \\
\hline $\begin{array}{l}\text { No } \\
\text { Yes }\end{array}$ & $\begin{array}{l}547(40.7) \\
796(59.3)\end{array}$ & $\begin{array}{l}292(41.1) \\
419(58.9)\end{array}$ & $\begin{array}{l}255(40.4) \\
377(59.6)\end{array}$ & 0.79 \\
\hline Marital status & & & & \\
\hline $\begin{array}{l}\text { Married/living with partner } \\
\text { Widowed/divorced/separated }\end{array}$ & $\begin{array}{l}289(21.6) \\
943(70.4)\end{array}$ & $\begin{array}{l}134(18.9) \\
518(72.9)\end{array}$ & $\begin{array}{l}155(24.6) \\
425(67.5)\end{array}$ & 0.04 \\
\hline $\begin{array}{l}\text { Never married } \\
\text { Level of health literacy }\end{array}$ & $108(8.0)$ & $58(8.2)$ & $50(7.9)$ & \\
\hline $\begin{array}{l}\text { Low } \\
\text { Adequate }\end{array}$ & $\begin{array}{l}533(41.6) \\
749(58.4)\end{array}$ & $\begin{array}{l}269(39.8) \\
407(60.2)\end{array}$ & $\begin{array}{l}264(43.6) \\
342(56.4)\end{array}$ & 0.17 \\
\hline $\begin{array}{l}\text { Up to date with BC screening at } \\
\text { baseline }\end{array}$ & & & & \\
\hline $\begin{array}{l}\text { No } \\
\text { Yes }\end{array}$ & $\begin{array}{l}161(12.0) \\
1176(88.0)\end{array}$ & $\begin{array}{l}90(12.7) \\
617(87.3)\end{array}$ & $\begin{array}{l}71(11.3) \\
559(88.7)\end{array}$ & 0.41 \\
\hline
\end{tabular}


Approximately $29 \%$ of study participants were lost to follow-up: $24.7 \%$ in the control group and $32.8 \%$ in the intervention group $(p<0.001)$. Table 2 examines loss to follow-up among the total sample and stratified by study arm. Participants who remained in the study were more likely to be younger and more educated, to have a higher income, supplemental insurance, and adequate health literacy, and to have been up to date at baseline screening. Participants who were not up to date at baseline were more likely to drop out from the intervention group but not the control group.

\section{Adherence Outcomes}

At study exit, a greater proportion of participants receiving the patient navigation intervention reported getting a mammogram than those in the control group $(93.3 \%$ and $87.5 \%$, respectively; $p<0.001)$. As shown in Fig. 2, among women who were not screening-adherent at baseline, the incidence of mammography screening at study exit was $73.4 \%$ for those in the intervention group, compared to only $45.6 \%$ for those in the control group $(p<0.001)$.

In multivariable analysis (Table 3 ), women in the intervention group had higher odds of having had a mammogram than women in the control group (odds ratio [OR] 2.26, $95 \%$ confidence interval [CI] 1.59-3.22). The rate of mammography screening at exit was also independently and positively associated with younger age (OR 2.12, 95 \% CI 1.50-3.00) and being up to date with screening at baseline (OR 14.05, 95 $\%$ CI 9.86-20.02).

We observed a significant interaction between the intervention and baseline mammogram status $(p=0.025$ for the interaction term). Among women who were not up to date at baseline, the intervention was associated with a significant

Table 2 Comparison of characteristics between participants completing the study and those lost to follow-up* for the entire population and stratified by intervention group

\begin{tabular}{|c|c|c|c|c|c|c|c|c|c|}
\hline & All participa & & & $\begin{array}{l}\text { Control gro } \\
N=956 \text { (50. }\end{array}$ & $\begin{array}{l}\text { p only } \\
\%)\end{array}$ & & $\begin{array}{l}\text { Patient navi } \\
N=949 \text { (49.8 }\end{array}$ & $\begin{array}{l}\text { ation group } \\
\%)\end{array}$ & \\
\hline & $\begin{array}{l}\text { Completed } \\
\text { exit } \\
\text { interview }\end{array}$ & $\begin{array}{l}\text { Lost to } \\
\text { follow-up }\end{array}$ & $\mathbf{P}^{\dagger}$ & $\begin{array}{l}\text { Completed } \\
\text { exit } \\
\text { interview }\end{array}$ & $\begin{array}{l}\text { Lost to } \\
\text { follow-up }\end{array}$ & $\mathbf{P}^{\dagger}$ & $\begin{array}{l}\text { Completed } \\
\text { exit } \\
\text { interview }\end{array}$ & $\begin{array}{l}\text { Lost to } \\
\text { follow-up }\end{array}$ & $\mathbf{P}^{\dagger}$ \\
\hline \multirow[t]{2}{*}{ Variable } & $(N=1358)$ & $(N=547)$ & & $(N=720)$ & $(N=236)$ & & $(N=638)$ & $(N=311)$ & \\
\hline & N (\%) & $\mathbf{N}(\%)$ & & $\mathbf{N}(\%)$ & $\mathbf{N}(\%)$ & & $\mathbf{N}(\%)$ & $\mathbf{N}(\%)$ & \\
\hline $\begin{array}{l}\text { Control group } \\
\text { Intervention group }\end{array}$ & $\begin{array}{l}720(53.0) \\
638(47.0)\end{array}$ & $\begin{array}{l}236(43.1) \\
311(56.9)\end{array}$ & $<0.001$ & & & & & & \\
\hline $\begin{array}{l}\text { Age group (years) } \\
>75 \\
\leq 75\end{array}$ & $\begin{array}{l}398(29.3) \\
960(70.7)\end{array}$ & $\begin{array}{l}221(40.4) \\
326(59.6)\end{array}$ & $<0.001$ & $\begin{array}{l}216(30.0) \\
504(70.0)\end{array}$ & $\begin{array}{l}98(41.5) \\
138(58.5)\end{array}$ & 0.001 & $\begin{array}{l}182(28.5) \\
456(71.5)\end{array}$ & $\begin{array}{l}123(39.5) \\
188(60.5)\end{array}$ & 0.001 \\
\hline $\begin{array}{l}\text { Education } \\
\leq \text { High school } \\
\text { diploma }\end{array}$ & $362(27.0)$ & $216(40.4)$ & $<0.001$ & $190(26.7)$ & $94(40.2)$ & $<0.001$ & $172(27.2)$ & $122(40.3)$ & $<0.001$ \\
\hline $\begin{array}{l}\text { High school diploma } \\
>\text { High school diploma }\end{array}$ & $\begin{array}{l}363(27.0) \\
618(46.0)\end{array}$ & $\begin{array}{l}138(25.8) \\
181(33.8)\end{array}$ & & $\begin{array}{l}201(28.3) \\
320(45.0)\end{array}$ & $\begin{array}{l}64(27.6) \\
74(31.9)\end{array}$ & & $\begin{array}{l}162(25.6) \\
298(47.2)\end{array}$ & $\begin{array}{l}74(24.4) \\
107(35.3)\end{array}$ & \\
\hline $\begin{array}{l}\text { Income } \\
\quad<\$ 20,000 \\
\geq \$ 20,000\end{array}$ & $\begin{array}{l}596(53.5) \\
519(46.5)\end{array}$ & $\begin{array}{l}285(65.8) \\
148(34.2)\end{array}$ & $<0.001$ & $\begin{array}{l}330(55.1) \\
269(44.9)\end{array}$ & $\begin{array}{l}133(68.6) \\
61(31.4)\end{array}$ & 0.001 & $\begin{array}{l}266(51.5) \\
250(48.5)\end{array}$ & $\begin{array}{l}152(63.6) \\
87(36.4)\end{array}$ & 0.002 \\
\hline Family history of $\mathrm{BC}$ & & & & & & & & & \\
\hline $\begin{array}{l}\text { No } \\
\text { Yes } \\
\text { Comorbidities }\end{array}$ & $\begin{array}{l}1063(79.6) \\
273(20.4)\end{array}$ & $\begin{array}{l}429(81.4) \\
98(18.6)\end{array}$ & 0.37 & $\begin{array}{l}567(80.4) \\
138(19.6)\end{array}$ & $\begin{array}{l}185(82.2) \\
40(17.8)\end{array}$ & 0.55 & $\begin{array}{l}496(78.6) \\
135(21.4)\end{array}$ & $\begin{array}{l}244(80.8) \\
58(19.2)\end{array}$ & 0.44 \\
\hline $\begin{array}{l}<3 \\
\geq 3\end{array}$ & $\begin{array}{l}510(38.7) \\
808(61.3)\end{array}$ & $\begin{array}{l}202(38.5) \\
323(61.5)\end{array}$ & 0.93 & $\begin{array}{l}266(38.0) \\
434(62.0)\end{array}$ & $\begin{array}{l}79(34.5) \\
150(65.5)\end{array}$ & 0.34 & $\begin{array}{l}244(39.5) \\
374(60.5)\end{array}$ & $\begin{array}{l}123(41.6) \\
173(58.4)\end{array}$ & 0.55 \\
\hline $\begin{array}{l}\text { Medicaid } \\
\text { No } \\
\text { Yes }\end{array}$ & $\begin{array}{l}1158(86.9) \\
174(13.1)\end{array}$ & $\begin{array}{l}446(84.6) \\
81(15.4)\end{array}$ & 0.19 & $\begin{array}{l}622(88.2) \\
83(11.8)\end{array}$ & $\begin{array}{l}193(84.3) \\
36(15.7)\end{array}$ & 0.12 & $\begin{array}{l}536(85.5) \\
91(14.5)\end{array}$ & $\begin{array}{l}253(84.9) \\
45(15.1)\end{array}$ & 0.81 \\
\hline $\begin{array}{l}\text { Medigap } \\
\text { No } \\
\text { Yes }\end{array}$ & $\begin{array}{l}547(40.7) \\
796(59.3)\end{array}$ & $\begin{array}{l}285(53.8) \\
245(46.2)\end{array}$ & $<0.001$ & $\begin{array}{l}292(41.1) \\
419(58.9)\end{array}$ & $\begin{array}{l}129(57.1) \\
97(42.9)\end{array}$ & $<0.001$ & $\begin{array}{l}255(40.4) \\
377(59.6)\end{array}$ & $\begin{array}{l}156(51.3) \\
148(48.7)\end{array}$ & 0.002 \\
\hline Marital status & & & & & & & & & \\
\hline $\begin{array}{l}\text { Married/living with partner } \\
\text { Widowed/divorced/ } \\
\text { separated }\end{array}$ & $\begin{array}{l}289(21.6) \\
943(70.4)\end{array}$ & $\begin{array}{l}98(18.3) \\
397(74.1)\end{array}$ & 0.25 & $\begin{array}{l}134(18.9) \\
518(72.9)\end{array}$ & $\begin{array}{l}42(18.2) \\
172(74.4)\end{array}$ & 0.87 & $\begin{array}{l}155(24.6) \\
425(67.5)\end{array}$ & $\begin{array}{l}56(18.3) \\
225(73.8)\end{array}$ & 0.09 \\
\hline $\begin{array}{l}\text { Never married } \\
\text { Up to date with BC screening }\end{array}$ & $\begin{array}{c}108(8.1) \\
\text { baseline }^{\S}\end{array}$ & $41(7.6)$ & & $58(8.2)$ & $17(7.4)$ & & $50(7.9)$ & $24(7.9)$ & \\
\hline $\begin{array}{l}\text { No } \\
\text { Yes }\end{array}$ & $\begin{array}{l}161(12.0) \\
1176(88.0)\end{array}$ & $\begin{array}{l}93(17.9) \\
428(82.1)\end{array}$ & 0.001 & $\begin{array}{l}90(12.7) \\
617(87.3)\end{array}$ & $\begin{array}{l}35(15.6) \\
189(84.4)\end{array}$ & 0.27 & $\begin{array}{l}71(11.3) \\
559(88.7)\end{array}$ & $\begin{array}{l}58(19.5) \\
239(80.5)\end{array}$ & 0.001 \\
\hline
\end{tabular}

Abbreviations: $B C$, breast cancer

*Includes individuals missing the outcome

†P-value calculated using Pearson's chi-squared tests

Individuals were considered at risk for low health literacy if they scored 6 or less on the REALM-R health literacy tool

sUp to date with breast cancer screening defined as self-reported mammography within 2 years of date of randomization

Note: Column percentages that do not equal $100 \%$ are due to missing data 


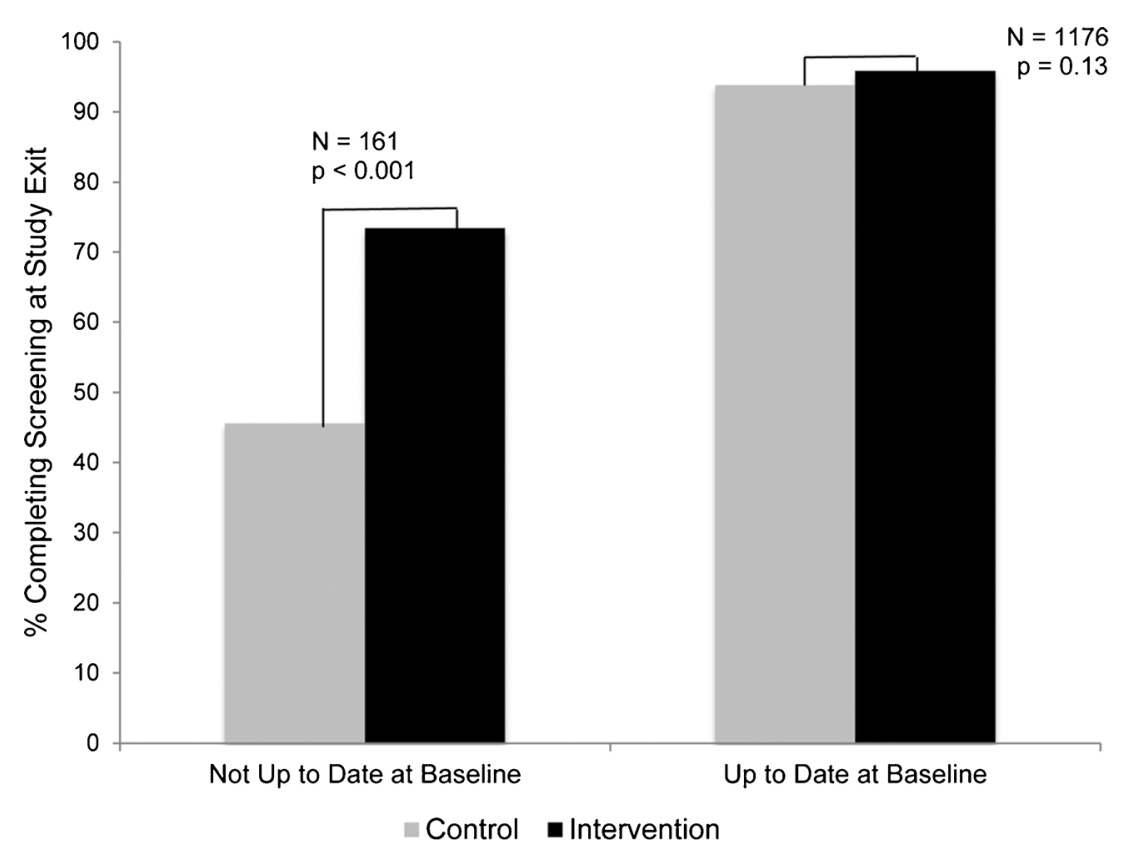

Fig. 2 Mammography screening rates at study exit (intervention vs. control) by baseline screening status

increase in the rate of screening at exit (OR 3.63, $95 \% \mathrm{CI}$ 2.10-6.26). The intervention remained significantly associated with mammography at exit among women who were up to date at baseline, though the effect size was smaller (OR 1.59, $95 \%$ CI 1.00-2.52). We did not observe statistically significant interaction terms between the intervention and either health literacy or participant age.

\section{DISCUSSION}

In a randomized controlled trial, we found that the use of patient navigation services among African American older women in an urban area increased the odds of self-reported receipt of a screening mammogram by the time of exit from the study. In addition, the association between patient navigation services and mammography was stronger for women who were not up to date with their screening at baseline.

Overall, our findings are consistent with previous studies that have shown patient navigator interventions to be effective in increasing screening mammography among minority or underserved communities. Recent systematic reviews have shown that patient navigation interventions improved screening mammography rates in medical and urban settings, and in participants who were racial/ethnic minorities. ${ }^{28,29}$ In a randomized controlled trial, Phillips and colleagues found that the integration of patient navigators into a health care system improved adherence to breast cancer screening among lowincome and predominantly middle-aged women. ${ }^{26}$ It is noteworthy that in our study, patient navigators were effective in improving adherence to breast cancer screening for patients receiving primary care throughout Baltimore City, even though the navigators were not integrated within the primary care teams. Three of the other five CPTD sites also found improvement in rates of breast cancer screening among the intervention group. ${ }^{40}$ Taken together, these studies suggest that a community-wide patient navigation program can help improve adherence to care by reducing barriers to care for patients across diverse health care systems. Furthermore, our data suggest that targeting of patient navigation to women who are not up to date with their mammography screening may be a more efficient use of resources.

Contrary to our hypothesis, the interaction between health literacy and intervention status was not significant. With multiple studies showing evidence of lower rates of screening mammography among women with low health literacy, ${ }^{45,46}$ targeting this population is critical. Further research is needed to explore ways to tailor patient navigation services for this high-risk population.

The patient navigation intervention was not modified based on age group. Despite controversy over the optimal age to stop breast cancer screening, studies suggest that screening persists, even among women with limited life expectancy. ${ }^{47}$ Analyses examining whether patient navigation is influenced by life expectancy rather than age would be an important next step. ${ }^{48}$ Future studies may consider tailoring patient navigators to women who may derive the greatest benefit from screening, while recognizing the need for informed decision-making among older women. ${ }^{49,50}$

Our study has several limitations. First, the focus on urban African American seniors in Baltimore City limits the generalizability of the study. Baltimore has a high percentage of 
Table 3 Adjusted odds ratios (OR) of being up to date with mammography screening at the exit interview among study participants $(N=1358)$

\begin{tabular}{|c|c|c|c|c|}
\hline \multirow[b]{3}{*}{ Predictor variable } & \multirow{2}{*}{\multicolumn{2}{|c|}{$\begin{array}{l}\text { Mammography screening at } \\
\text { exit interview }\end{array}$}} & \multirow{2}{*}{\multicolumn{2}{|c|}{$\begin{array}{l}\text { Mammography screening at } \\
\text { exit interview }\end{array}$}} \\
\hline & & & & \\
\hline & $\mathrm{OR}^{*}(95 \% \mathrm{CI})$ & $P$ value & $\mathrm{OR}^{*}(95 \% \mathrm{CI})$ & $P$ value \\
\hline \multicolumn{5}{|l|}{ Intervention } \\
\hline Control, PEM (ref) & 1.00 & & 1.00 & \\
\hline Patient navigation + PEM & $2.26(1.59-3.42)$ & $<0.001$ & $2.16(1.41-3.30)$ & $<0.001$ \\
\hline \multicolumn{5}{|l|}{ Age (years) } \\
\hline$\geq 76$ (ref) & 1.00 & & 1.00 & \\
\hline $65-75$ & $2.12(1.50-3.00)$ & $<0.001$ & $2.13(1.40-3.23)$ & $<0.001$ \\
\hline \multicolumn{5}{|l|}{ Education } \\
\hline$<$ High school diploma (ref) & 1.00 & & 1.00 & 0.86 \\
\hline High school diploma & $1.05(0.65-1.68)$ & 0.85 & $1.05(0.59-1.89)$ & \\
\hline >High School Diploma & $0.80(0.50-1.29)$ & 0.36 & $0.84(0.46-1.53)$ & 0.57 \\
\hline \multicolumn{5}{|l|}{ Income } \\
\hline$<\$ 20,000 /$ year (ref) & 1.00 & & 1.00 & 0.98 \\
\hline$\geq \$ 20,000 /$ year & $1.02(0.65-1.62)$ & 0.92 & $0.99(0.59-1.68)$ & \\
\hline \multicolumn{5}{|l|}{ Marital status } \\
\hline Never married (ref) & 1.00 & & 1.00 & \\
\hline Widowed/divorced/separated & $1.37(0.77-2.44)$ & 0.28 & $1.40(0.70-2.79)$ & 0.35 \\
\hline Married/living with partner & $1.14(0.66-2.73)$ & 0.41 & $1.21(0.53-2.79)$ & 0.65 \\
\hline \multicolumn{5}{|l|}{ Family history of breast cancer } \\
\hline No (ref) & 1.00 & & 1.00 & \\
\hline Yes & $1.05(0.68-1.63)$ & 0.84 & $1.04(0.62-1.74)$ & 0.88 \\
\hline \multicolumn{5}{|l|}{ Comorbidities } \\
\hline$<3$ (ref) & 1.00 & & 1.00 & \\
\hline$\geq 3$ & $1.05(0.75-1.48)$ & 0.77 & $1.01(0.67-1.54)$ & 0.95 \\
\hline \multicolumn{5}{|l|}{ Medicaid } \\
\hline No (ref) & 1.00 & & 1.00 & \\
\hline Yes & $0.82(0.50-1.36)$ & 0.45 & $0.93(0.50-1.75)$ & 0.83 \\
\hline \multicolumn{5}{|l|}{ Medigap } \\
\hline No (ref) & 1.00 & & & \\
\hline Yes & $1.11(0.77-1.60)$ & 0.58 & $1.22(0.79-1.88)$ & 0.38 \\
\hline \multicolumn{5}{|l|}{ Level of health literacy } \\
\hline Low (ref) & 1.00 & & 1.00 & \\
\hline Adequate & $1.30(0.73-1.64)$ & 0.19 & $1.20(0.73-1.97)$ & 0.73 \\
\hline \multicolumn{5}{|l|}{ Baseline mammogram status } \\
\hline Not up to date (ref) & 1.00 & & 1.00 & \\
\hline Up to date & $14.05(9.86-20.02)$ & $<0.001$ & $13.67(8.97-20.82)$ & $<0.001$ \\
\hline
\end{tabular}

Abbreviations: CI, confidence interval; PEM, printed educational materials only; Ref, reference group

*Odds ratios (OR) and $95 \%$ CIs were calculated using weighted multiple logistic regression models adjusted for variables in the table

African Americans with low socioeconomic status $(79.6 \%$ of the population graduated from high school, median household income is $\$ 40,803$, and $23.4 \%$ live below the federal poverty level), ${ }^{51}$ and examination of interventions that reduce disparities in this high-risk population is critical. Related to this, the Baltimore CPTD study sample is more likely to be younger than potentially eligible participants based on the 2008 and 2009 Medicare roster $(65.0 \%$ age $65-74$ in CPTD vs. $56.1 \%$ in the Medicare roster, $p<0.005)$, which may affect generalizability. Second, a large proportion of women were lost to follow-up, disproportionately so in the intervention group. We are uncertain why more women dropped out of the intervention despite the frequent contact and high levels of satisfaction with the intervention reported among those who remained. It is plausible that the larger dropout rate in this group was due to contact fatigue among some women. It is also possible that some participants felt uncomfortable with navigation (e.g., due to perceived loss of privacy when navigators were from the same community), which may have deterred some from following up and/or receiving screening. In order to reduce bias, we used weighted logistic regression with the inverse probability method in order to 1) address the differential loss by group status and 2) account for observable differences in baseline characteristics between participants who completed the study and those who were lost to followup. This approach, however, is unable to account for unobservable differences that may be associated with attrition. Third, all study variables, including the outcome variable, were obtained by self-report. Studies have shown that selfreported use of mammography tends to be overstated, ${ }^{52}$ though it would not necessarily be differential between the control and intervention arm participants. While the potential for over-reporting of screening in the intervention arm due to social desirability bias is plausible, independent analysis using claims data by RTI International, a non-profit research organization, for the Centers for Medicare and Medicaid Services (CMS) showed higher mammography rates in the intervention group across four study sites. ${ }^{40}$ Finally, the costs of the CPTD program were evaluated in the RTI report, revealing a cost of approximately $\$ 3,000$ per person enrolled in the Baltimore site. A formal cost-benefit analysis of this program is an important direction for future research. ${ }^{53,54}$ Strengths of the 
study include its focus on a vulnerable population, the use of a community-based participatory approach, a randomized controlled design, and examination of potential moderators of the intervention.

In conclusion, our study adds to the evidence that patient navigation services are positively associated with improving utilization rates of breast cancer screening services for minority women, especially among women who are not up to date on mammography screening. Future interventions that target women who are not up to date with screening are likely to be a more efficient use of patient navigation services. As health care access and delivery continues to evolve under payment models encouraged by the Affordable Care Act, patient navigation programs may be an effective way to improve screening and address disparities in cancer care among racial/ethnic minority populations and older adults.

Author Contributions: Dr. Marshall and Ms. Mbah had full access to all of the data in the study, and both take responsibility for the integrity of the data and the accuracy of the data analysis.

Study Concept and Design: Ford, Marshall, Mbah, Phelan-Emrick, and Pollack.

Acquisition, Analysis, or Interpretation of Data: Marshall, Mbah, Ford, Phelan-Emrick, Ahmed, Bone, Wenzel, Shapiro, Howerton, Johnson, and Pollack.

Drafting of the Manuscript: Marshall, Mbah, Ford, and Pollack.

Critical Revision of the Manuscript for Important Intellectual Content: All authors.

Statistical Analysis: Marshall, Mbah, and Pollack.

Obtained Funding: Ford, Marshall, Mbah, and Pollack.

Administrative, Technical, or Material Support: Ford, Marshall, Mbah, and Pollack.

\section{Study Supervision: Ford and Pollack.}

Funding/Support: This work was funded by the CPTD for Ethnic and Racial Minorities of the Centers for Medicare and Medicaid Services (cooperative agreement \#1AOCMS300066), and supported in part by the Community Networks Program (grant U54CA153710) of the National Cancer Institute. In addition, Dr. Jessie Kimbrough Marshall was supported by the National Research Service Award (5 T32 HLOO718034 O) from the Health Services and Resources Administration (HRSA), Ms. Olive Mbah was supported by the Community Networks Program (grant U54CA153710) of the National Cancer Institute, and Dr. Craig Pollack was supported by the National Cancer Institute and Office of Behavioral and Social Sciences (KO7 CA151910).We would like to acknowledge partial support for the statistical analysis from the $\mathrm{Na}$ tional Center for Research Resources and the National Center for Advancing Translational Sciences (NCATS) of the National Institutes of Health through grant number 1UL1TR001079.

Role of the Sponsor(s): None of the aforementioned funders had a role in any stage of this study.

Contributors: The authors would like to sincerely thank participants in the CPTD study, staff, and our community partners, including members of the Community Advisory Committee. We acknowledge Ms. Melissa Plegue and Dr. Brady West of the University of Michigan Center for Statistical Consultation and Research and Dr. Hsin-Chieh Yeh from Johns Hopkins University for their assistance with the statistical analysis.
Conflicts of Interest: The authors declare that they do not have a conflict of interest.

Disclaimer: The opinions expressed in this article/publication are the authors' own and do not reflect the view of the Centers for Medicare and Medicaid Services, the Department of Health and Human Services, or the United States government. Manuscript contributions by Dr. Howerton were accomplished in her personal capacity and represent work completed while employed at the Johns Hopkins School of Medicine.

Corresponding Author: Jean G. Ford, MD; Department of MedicineThe Brooklyn Hospital Center, Brooklyn, NY, USA (e-mail:jgf9001@nyp.org).

\section{REFERENCES}

1. Siegel R, Ma J, Zou Z, Jemal A. Cancer statistics, 2014. CA Cancer J Clin. 2014;64(1):9-29.

2. American Cancer Society. Breast Cancer Facts \& Figures 2013-2014 Atlanta, GA: American Cancer Society; 2013. Report No.: http://www. cancer.org/acs/groups/content/@research/documents/document/ acspc-042725.pdf. [last accessed June 1, 2015.]

3. US Preventive Services Task Force. Screening for breast cancer: U.S. Preventive Services Task Force recommendation statement. Ann Intern Med. 2009 Nov 17;151(10):716,26, W-236.

4. Harper S, Lynch J, Meersman SC, Breen N, Davis WW, Reichman MC. Trends in area-socioeconomic and race-ethnic disparities in breast cancer incidence, stage at diagnosis, screening, mortality, and survival among women ages 50 years and over (1987-2005). Cancer Epidemiol Biomarkers Prev. 2009; 18(1):121-31.

5. Kagawa-Singer M, Dadia AV, Yu MC, Surbone A. Cancer, culture, and health disparities: time to chart a new course? CA Cancer $\mathrm{J}$ Clin. 2010;60(1): 12-39.

6. Hershman D, McBride R, Jacobson JS, Lamerato L, Roberts K, Grann VR, et al. Racial disparities in treatment and survival among women with early-stage breast cancer. J Clin Oncol. 2005;23(27):6639-46.

7. Silber JH, Rosenbaum PR, Clark AS, Giantonio BJ, Ross RN, Teng Y, et al. Characteristics associated with differences in survival among black and white women with breast cancer. JAMA. 2013;310(4):389-97.

8. Howlader N, Noone AM, Krapcho M, Garshell J, Neyman N, Altekruse SF, Kosary CL, Yu M, Ruhl J, Tatalovich Z, Cho H, Mariotto A, Lewis DR, Chen HS, Feuer EJ, Cronin KA (eds). SEER Cancer Statistics Review, 19752010, National Cancer Institute. http://seer.cancer.gov/csr/1975 2010/, based on November 2012 SEER data submission, posted to the SEER web site, April 2013. Bethesda, MD: National Cancer Institute; 2013. [last accessed June 1, 2015]

9. Martires KJ, Kurlander DE, Minwell GJ, Dahms EB, Bordeaux JS. Patterns of cancer screening in primary care from 2005 to 2010. Cancer. 2014;120(2):253-61.

10. Curtis E, Guale C, Haggstrom D, Smith-Bindman R. Racial and ethnic differences in breast cancer survival: how much is explained by screening, tumor severity, biology, treatment, comorbidities, and demographics? Cancer. 2008;112(1):171-80.

11. Smith-Bindman R, Miglioretti DL, Lurie N, Abraham L, Barbash RB, Strzelczyk J, et al. Does utilization of screening mammography explain racial and ethnic differences in breast cancer? Ann Intern Med. 2006;144(8):541-53.

12. Scott TL, Gazmararian JA, Williams MV, Baker DW. Health literacy and preventive health care use among Medicare enrollees in a managed care organization. Med Care. 2002;40(5):395-404.

13. Freeman HP, Chu KC. Determinants of cancer disparities: barriers to cancer screening, diagnosis, and treatment. Surg Oncol Clin N Am. 2005; 14(4):655-69. v.

14. Freeman HP. Patient navigation: a community based strategy to reduce cancer disparities. J Urban Health. 2006;83(2):139-41.

15. Freeman HP. A model patient navigation program. Oncol Issues. 2004; 19:44-6.

16. Dohan D, Schrag D. Using navigators to improve care of underserved patients: current practices and approaches. Cancer. 2005; 104(4):848-55.

17. Robinson-White S, Conroy B, Slavish KH, Rosenzweig M. Patient navigation in breast cancer: a systematic review. Cancer Nurs. 2010;33(2):127-40. 
18. Peek ME, Tang H, Alexander GC, Chin MH. National prevalence of lifestyle counseling or referral among African-Americans and whites with diabetes. J Gen Intern Med. 2008;23(11):1858-64.

19. Vargas RB, Ryan GW, Jackson CA, Rodriguez R, Freeman HP. Characteristics of the original patient navigation programs to reduce disparities in the diagnosis and treatment of breast cancer. Cancer. 2008; 113(2):426-33.

20. Musa D, Schulz R, Harris R, Silverman M, Thomas SB. Trust in the health care system and the use of preventive health services by older black and white adults. Am J Public Health. 2009;99(7):1293-9.

21. Freeman HP, Muth BJ, Kerner JF. Expanding access to cancer screening and clinical follow-up among the medically underserved. Cancer Pract. 1995;3(1):19-30.

22. Burhansstipanov L, Wound DB, Capelouto N, Goldfarb F, Harjo L, Hatathlie L, et al. Culturally relevant "Navigator" patient support. The Native sisters. Cancer Pract. 1998;6(3):191-4.

23. Oluwole SF, Ali AO, Adu A, Blane BP, Barlow B, Oropeza R, et al. Impact of a cancer screening program on breast cancer stage at diagnosis in a medically underserved urban community. J Am Coll Surg. 2003;196(2):180-8.

24. Dignan MB, Burhansstipanov L, Hariton J, Harjo L, Rattler T, Lee R, et al. A comparison of two Native American Navigator formats: face-to-face and telephone. Cancer Control. 2005;12(Suppl 2):28-33.

25. Han HR, Lee H, Kim MT, Kim KB. Tailored lay health worker intervention improves breast cancer screening outcomes in non-adherent KoreanAmerican women. Health Educ Res. 2009;24(2):318-29.

26. Phillips CE, Rothstein JD, Beaver $\mathbf{K}$, Sherman BJ, Freund KM, Battaglia TA. Patient navigation to increase mammography screening among inner city women. J Gen Intern Med. 2011;26(2):123-9.

27. Percac-Lima S, Ashburner JM, Bond B, Oo SA, Atlas SJ. Decreasing disparities in breast cancer screening in refugee women using culturally tailored patient navigation. J Gen Intern Med. 2013;28(11):1463-8.

28. Wells KJ, Battaglia TA, Dudley DJ, Garcia R, Greene A, Calhoun E, et al. Patient navigation: state of the art or is it science? Cancer. 2008;113(8):1999-2010.

29. Paskett ED, Harrop JP, Wells KJ. Patient navigation: an update on the state of the science. CA Cancer J Clin. 2011;61(4):237-49.

30. Clark CR, Baril N, Kunicki M, Johnson N, Soukup J, Ferguson K, et al. Addressing social determinants of health to improve access to early breast cancer detection: results of the Boston REACH 2010 Breast and Cervical Cancer Coalition Women's Health Demonstration Project. J Womens Health (Larchmt). 2009; 18(5):677-90.

31. Bone LR, Edington K, Rosenberg J, Wenzel J, Garza MA, Klein C, et al. Building a navigation system to reduce cancer disparities among urban Black older adults. Prog Community Health Partnersh. 2013;7(2):209-18.

32. Braun KL, Allison A, Tsark JU. Using community-based research methods to design cancer patient navigation training. Prog Community Health Partnersh. 2008;2(4):329-40.

33. Kanekar S, Petereit D. Walking forward: a program designed to lower cancer mortality rates among American Indians in western South Dakota. S D Med. 2009;62(4):151-3. 155-7, 159.

34. Ma GX, Shive S, Tan Y, Gao W, Rhee J, Park M, et al. Community-based colorectal cancer intervention in underserved Korean Americans. Cancer Epidemiol. 2009;33(5):381-6.

35. Horowitz CR, Arniella A, James S, Bickell NA. Using community-based participatory research to reduce health disparities in East and Central Harlem. Mt Sinai J Med. 2004;71(6):368-74.

36. Smith RA, Saslow D, Sawyer KA, Burke W, Costanza ME, Evans WP 3rd, et al. American Cancer Society guidelines for breast cancer screening: update 2003. CA Cancer J Clin. 2003;53(3):141-69.
37. Martinez KA, Pollack CE, Phelan DF, Markakis D, Bone L, Shapiro G, et al. Gender differences in correlates of colorectal cancer screening among Black Medicare beneficiaries in Baltimore. Cancer Epidemiol Biomarkers Prev. 2013;22(6): 1037-42.

38. Horne HN, Phelan-Emrick DF, Pollack CE, Markakis D, Wenzel J, Ahmed S, et al. Effect of patient navigation on colorectal cancer screening in a community-based randomized controlled trial of urban African American adults. Cancer Causes Control. 2015;26(2):239-46.

39. Braun KL, Thomas WL Jr, Domingo JL, Allison AL, Ponce A, Haunani Kamakana P, et al. Reducing cancer screening disparities in medicare beneficiaries through cancer patient navigation. J Am Geriatr Soc. 2015;63(2):365-70.

40. RTI International. Evaluation of the Cancer Prevention and Treatment Demonstration for Ethnic and Racial Minorities. Centers for Medicare and Medicaid Services; March 2012. Report No.: CMS Contract No. 500-000024 TO\#27.

41. Bass PF 3rd, Wilson JF, Griffith CH. A shortened instrument for literacy screening. J Gen Intern Med. 2003;18(12):1036-8.

42. Murphy PW, Davis TC, Long SW, Jackson RH, Decker BC. Rapid estimate of adult literacy in medicine (REALM): A quick reading test for patients. J Read. 1993;37(2): 124-30.

43. Hogan JW, Roy J, Korkontzelou C. Handling drop-out in longitudinal studies. Stat Med. 2004;23(9):1455-97.

44. Seaman SR, White IR. Review of inverse probability weighting for dealing with missing data. Stat Methods Med Res. 2013;22(3):278-95.

45. Pagan JA, Brown CJ, Asch DA, Armstrong K, Bastida E, Guerra C. Health literacy and breast cancer screening among Mexican American women in South Texas. J Cancer Educ. 2012;27(1):132-7.

46. Roman L, Meghea C, Ford S, Penner L, Hamade H, Estes T, et al. Individual, provider, and system risk factors for breast and cervical cancer screening among underserved Black, Latina, and Arab women. J Womens Health (Larchmt). 2014;23(1):57-64.

47. Block LD, Jarlenski MP, Wu AW, Bennett WL. Mammography use among women ages $40-49$ after the 2009 U.S. Preventive Services Task Force recommendation. J Gen Intern Med. 2013;28(11):1447-53.

48. Bellizzi KM, Breslau ES, Burness A, Waldron W. Prevalence of cancer screening in older, racially diverse adults: still screening after all these years. Arch Intern Med. 2011;171(22):2031-7.

49. Schonberg MA, McCarthy EP, Davis RB, Phillips RS, Hamel MB. Breast cancer screening in women aged 80 and older: results from a national survey. J Am Geriatr Soc. 2004;52(10):1688-95.

50. Schonberg MA, Hamel MB, Davis RB, Griggs MC, Wee CC, Fagerlin A. Development and evaluation of a decision aid on mammography screening for women 75 years and older. JAMA Intern Med. 2014;174(3):417-24.

51. State and County QuickFacts. [Internet]. Maryland: U.S Census Bureau; 2014 [updated July 8, 2014; cited October 13, 2014]. Available from: http://quickfacts.census.gov/qfd/states/24/24510.html. [last accessed June 1, 2015]

52. Allgood KL, Rauscher GH, Whitman S, Vasquez-Jones G, Shah AM. Validating self-reported mammography use in vulnerable communities: findings and recommendations. Cancer Epidemiol Biomarkers Prev. 2014;23(8):1649-58.

53. Markossian TW, Calhoun EA. Are breast cancer navigation programs cost-effective? Evidence from the Chicago Cancer Navigation Project. Health Policy. 2011;99(1):52-9.

54. Bensink ME, Ramsey SD, Battaglia T, Fiscella K, Hurd TC, McKoy JM, et al. Costs and outcomes evaluation of patient navigation after abnormal cancer screening: evidence from the Patient Navigation Research Program. Cancer. 2014;120(4):570-8. 